\title{
Statins and Diabetes Risk
}

\author{
Sumon Rahman Chowdhury ${ }^{1 *}$, Sultana Ruma Alam², Rezaul Haider Chowdhury ${ }^{3}$ and Shangkar Barua ${ }^{4}$ \\ ${ }^{1}$ Department of Diabetes, Endocrinology and Metabolism, Chittagong Diabetic General Hospital, Bangladesh \\ ${ }^{2}$ Associate Professor, Department of Anatomy, Institute of Applied Health Sciences, Bangladesh \\ ${ }^{3}$ Department of Internal Medicine, Chittagong Diabetic General Hospital, Bangladesh
}

${ }^{4}$ Assistant Professor, Department of Endocrinology,, Cox's Bazar Medical College, Bangladesh

Submission: January 28, 2021; Published: February 25, 2021

*Corresponding author: Sumon Rahman Chowdhury, Senior Medical Officer, Department of Diabetes, Endocrinology and Metabolism, Chittagong Diabetic General Hospital, Chittagong, Bangladesh

\begin{abstract}
Statins are a class of drugs that inhibit the HMG Co-A reductase enzyme and subsequently reduce the cholesterol levels. HMG Co-A reductase enzyme is involved in the cholesterol synthesis in the liver and accounts for $70 \%$ of the production of total body cholesterol. High cholesterol levels attribute to cardiovascular disease in high-risk individuals. Statins have been found to reduce CVD endpoints in the initial stages of the disease (secondary prevention) but evidence is still weak to support statin therapy in those without CVD but with high cholesterol levels (primary prevention). Statins are also associated with certain adverse effects like muscle pain, incident diabetes and elevated liver enzymes and occasionally muscle damage; although very rare. In this review I shall explore one of these adverse effects of statin therapy particularly the link between statins and incident diabetes in the following report and try to shed some light into this controversial topic.
\end{abstract}

Keywords: Diabetes; Statins; Cardiovascular Disease

\section{Introduction}

There is an increased risk of incident diabetes with statin use, which may be limited to those with diabetes risk factors.

I. These patients may benefit additionally from diabetes screening when on statin therapy.

II. In an analysis of one of the initial studies suggesting that statins are linked to increased risk of diabetes, the cardiovascular event rate reduction with statins outweighed the risk of incident diabetes even for patients at highest risk for diabetes [1].

III. The absolute risk increase was small (over 5 years of follow-up, $1.2 \%$ of participants on placebo developed diabetes and $1.5 \%$ on rosuvastatin) [2].

IV. A meta-analysis of 13 randomized statin trials with 91,140 participants showed an odds ratio of 1.09 for a new diagnosis of diabetes, so that (on average) treatment of 255 patients with statins for 4 years resulted in one additional cause of diabetes, while simultaneously preventing 5.4 vascular events among 255 patients [3-4].

V. The relative risk-benefit ratio favoring statins is further supported by meta-analysis of individual data of over
170,000 persons from 27 randomized trials. This demonstrated that individuals at low risk of vascular disease, including those undergoing primary prevention, received benefits from statins that included reductions in major vascular events and vascular death without increase in incidence of cancer or deaths from another causes [5-6].

In this review I shall explore one of these adverse effects of statin therapy particularly the link between statins and incident diabetes in the following report and try to shed some light into this controversial topic.

\section{Discussion}

\section{Classification, Mechanisms and Recommendations for Statin Therapy}

Several statin preparations are available in the market like atorvastatin, rosuvastatin, fluvastatin, lovastatin, pravastatin, and simvastatin. All of these agents are equally effective at reducing cholesterol and vary only in their adverse effects with simvastatin and pravastatin exhibiting a slight superiority [5]. The various statins also differ in their pharmacokinetics and dosing and are outlined in the tables below (Table $1 \& 2$ ) [7-8]. 
Table 1: Pharmacokinetics of statins.

\begin{tabular}{|c|c|c|c|c|}
\hline & Isoenzyme & Lipophilic & Protein binding (\%) & Half Life \\
(hr)
\end{tabular}

Table 2: Dosing of statins.

\begin{tabular}{|c|c|c|c|c|c|c|c|c|}
\hline Atorva & Fluva & Pitava & Lova & Prava* & Rosuva* & Simvastatin + Ezetimibe & Simvastatin & $\%$ LDL \\
\hline$\ldots . .$. & $40 \mathrm{mg}$ & $1 \mathrm{mg}$ & $20 \mathrm{mg}$ & $20 \mathrm{mg}$ & $\ldots .$. & $\ldots . .$. & $10 \mathrm{mg}$ & $30 \%$ \\
\hline $10 \mathrm{mg}$ & $80 \mathrm{mg}$ & $2 \mathrm{mg}$ & 40 or $80 \mathrm{mg}$ & $40 \mathrm{mg}$ & $\cdots$. & $\cdots$ & $20 \mathrm{mg}$ & $38 \%$ \\
\hline $20 \mathrm{mg}$ & $\ldots .$. & $4 \mathrm{mg}$ & $80 \mathrm{mg}$ & $80 \mathrm{mg}$ & $5 \mathrm{mg}$ & $10 / 10 \mathrm{mg}$ & $40 \mathrm{mg}$ & $41 \%$ \\
\hline $40 \mathrm{mg}$ & $\cdots$. & $\cdots \cdots$ & $\cdots \cdots$ & $\cdots$ & $10 \mathrm{mg}$ & $10 / 20 \mathrm{mg}$ & $80 \mathrm{mg}$ & $47 \%$ \\
\hline $80 \mathrm{mg}$ & $\ldots$. & $\ldots .$. & $\ldots$. & $\ldots .$. & $20 \mathrm{mg}$ & $10 / 40 \mathrm{mg}$ & $\ldots$. & $55 \%$ \\
\hline$\ldots$. & $\ldots$. & $\ldots$. & $\ldots$. & $\ldots$. & $40 \mathrm{mg}$ & $10 / 80 \mathrm{mg}$ & $\ldots .$. & $63 \%$ \\
\hline
\end{tabular}

Atorva= Atorvastatin; Fluva= Fluvastatin; Pitava= Pitavastatin; Lova= Lovastatin; Prava= Pravastatin; Rosuva= Rosuvastatin; Simva= Simvastatin; *Hydrophyllic agents

\section{Mechanisms of Action}

Statins competitively inhibit the HMG CoA reductase enzyme which is involved in the biosynthesis of cholesterol. They are molecularly similar to the enzyme and inhibit the conversion from HMG CoA to mevalonate which further leads to inhibition of cholesterol synthesis and ultimately cholesterol reduction via several pathways. The following figure demonstrate how statins affect cholesterol biosynthesis (Figure 1) [9]. Statin therapy is initiated after failure of lifestyle modifications by determining risk category (Table 3) [10].

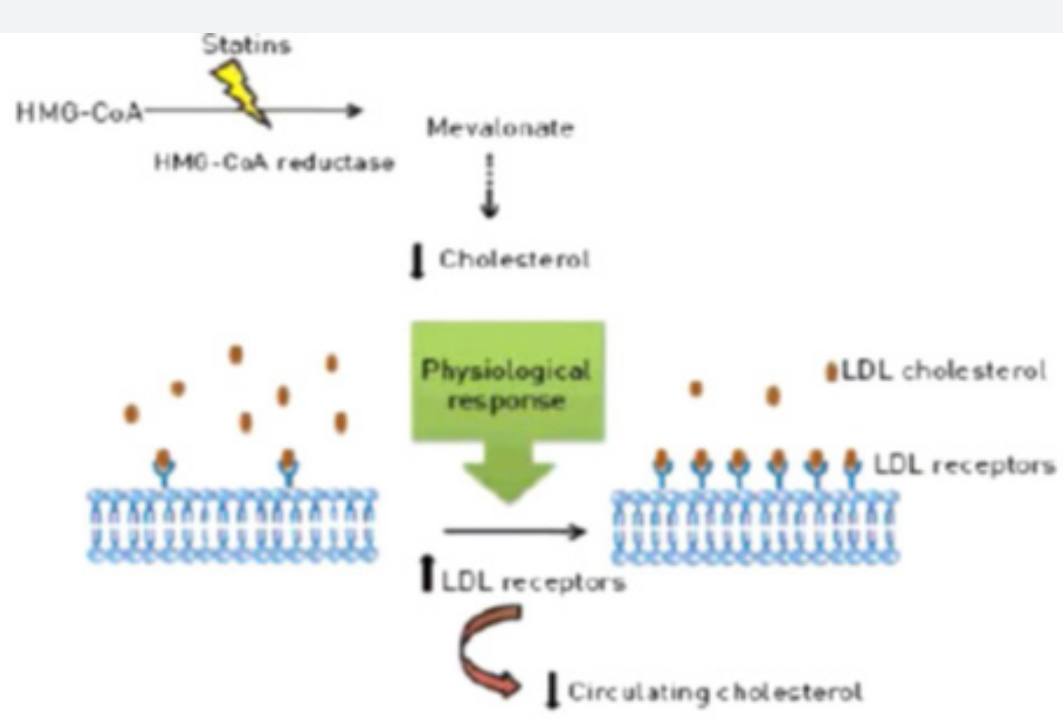

Figure 1: Mechanisms of action of statins. 
Table 3: Risk category determination for statin therapy.

\begin{tabular}{|c|c|c|c|}
\hline Risk Category & LDL Goal & $\begin{array}{l}\text { LDL Level at Which to } \\
\text { Initiate TLC }\end{array}$ & LDL Level at Which to Consider Drug Therapy \\
\hline $\begin{array}{l}\text { CHD or CHD Risk Equiva- } \\
\text { lents } \\
\text { (10-year risk }>20 \%)\end{array}$ & $\begin{array}{c}<100 \mathrm{mg} / \mathrm{dL}<70 \mathrm{mg} / \\
\mathrm{dL} \text { optional }\end{array}$ & $\geq 100 \mathrm{mg} / \mathrm{dL}$ & $\geq 130 \mathrm{mg} / \mathrm{dL}$ (100-129 mg/dL: drug optional) \\
\hline $\begin{array}{c}2+\text { Risk factors } \\
(10 \text {-year risk <20\%) }\end{array}$ & $<130 \mathrm{mg} / \mathrm{dL}$ & $\geq 130 \mathrm{mg} / \mathrm{d}$ & $\begin{array}{c}10 \text {-year risk } 10-20 \% \text { : > } 130 \mathrm{mg} / \mathrm{dL} \\
10 \text {-year risk < } 10 \% \text { : > } 160 \mathrm{mg} / \mathrm{dL}\end{array}$ \\
\hline 0-1 Risk factor & $<160 \mathrm{mg} / \mathrm{dL}$ & $\geq 160 \mathrm{mg} / \mathrm{dL}$ & $>90 \mathrm{mg} / \mathrm{dL}$ (160-180 mg/dL: LDL- lowering drug optional) \\
\hline
\end{tabular}

\section{Evidence for the Benefits of Statin Therapy}

Diabetes is associated with a two to four-fold increased risk of CVD compared to non-diabetics and intensive management of all CVD risk factors, including dyslipidemia, is of paramount importance in diabetics [11]. Additionally, the beneficial effects of LDL-C lowering with statins apply to people with and without diabetes [12]. Several trials have demonstrated the efficacy of statins for the primary and secondary prevention of CVD in diabetic individuals with the latter showing significant reductions in CVD associated mortality and morbidity.

\section{Primary Prevention}

i. HPS Study [13]: In the diabetes subgroup, 40mg Simvastatin reduced CV events and stroke by $27 \%$ and $25 \%$ respectively compared to placebo.

ii. CARDS Study [14] (10 mg Atorvastatin): Statin therapy should be advocated for all patients with T2DM and other risk factors irrespective of their LDL levels.

iii. CTT Collaborators [15]: Diabetics had a 9\% reduction in all-cause mortality and $21 \%$ reduction in major vascular events per mmol/L LDL-C reduction.

iv. ASPEN [16] (10 mg Atorvastatin): LDL-C was reduced by $29 \%$ with Atorvastatin compared to placebo but the primary endpoints of CVD were not significantly reduced. This poor showing was due to the study design and protocol changes.

\section{Secondary Prevention}

i. PROVE-IT TIMI [17] (40 mg Pravastatin vs. $80 \mathrm{mg}$ Atorvastatin): Primary end point of CVD was reduced by $16 \%$ and CRP was also reduced which had positive benefit in CV event reduction irrespective of decreased LDL [18].

ii. TNT Study [19] (10 mg vs. $80 \mathrm{mg}$ Atorvastatin): Significant 25\% reduction in major cardiovascular events in the high dose group with LDL lowering to $2 \mathrm{mmol} / \mathrm{l}$ compared to $2.5 \mathrm{mmol} / \mathrm{l}$ in the low dose group.

iii. A to $\mathbf{Z}$ trial [20] (20 mg Simvastatin titrated to $80 \mathrm{mg}$ ): A reduction of $1.6 \mathrm{mmol} / \mathrm{l}$ in the intensive group was seen with reduction in primary outcome (CVD, nonfatal MI, ACS and stroke) which, however, was not statistically significant. iv. IDEAL trial [21] (Simvastatin $20 \mathrm{mg}$ vs. Atorvastatin 80 $\mathrm{mg}$ ): No significant reduction in major cardiovascular events but reduction in nonfatal AMI, coronary revascularization, and PVD.

\section{Statins and Incident Diabetes}

Recent meta-analyses point to a relative increase in diabetes with prolonged statin use with this increased risk being attributed to the statin dose [22-24]. US FDA issued a warning in 2012 linking statins with increased risk of new onset DM and worsening glycaemic status in pre-existing diabetic patients. Several trials have investigated the incidence of diabetes with statin therapy and they are outlined below:

1. WOSCOPS [25] study (Pravastatin $40 \quad \mathrm{mg}$ ): $30 \%$ decreased incidence of diabetes with pravastatin therapy as compared to placebo.

2. JUPITER [26] study (Rosuvastatin $20 \mathrm{mg}$ ): Associated with significant reductions in the incidence of major coronary events. There was however a significant increase in the rate of physician-reported diabetes $(26 \%)$ and an increase in median HbA1C.

3. PROSPER [27] study (Pravastatin $40 \mathrm{mg}$ ): Significant LDL-C reduction by $34 \%$ but incidentally a $32 \%$ higher incidence of diabetes.

4. Meta-analysis by Rajpathak et al [23]: studies were carried out to analyze the outcomes of the WOSCOPS, ASCOT-LLA, JUPITER, HPS, LIPID study and the CORONA study and showed an average $13 \%$ higher incidence of diabetes.

5. Meta-analysis by Preiss and Waters: high dose statins resulted in increased incidence of diabetes $[24,28]$.

Statins differ in their lipophilic (atorvastatin, lovastatin, and simvastatin) as well as hydrophilic properties (pravastatin and rosuvastatin) and the results of the CORALL study showed a significant increase in $\mathrm{HbA1C}$ with high dose rosuvastatin and atorvastatin [29-30].

\section{Mechanisms of Incident Diabetes and Statin use}

- There is no clear-cut cause-effect relationship, but postulates include decreased insulin sensitivity with increasing statin doses and decreased adiponectin with loss of antiproliferative and antiangiogenic properties. 
- Animal studies show decreased GLUT4 and increased GLUT1 expression with atorvastatin with defective insulin signaling and glucose transport defects in the adipocyte leading to insulin resistance.

- Abnormal regulation of cholesterol within the cell thereby impairing $\beta$ cell function.

The results of these studies raised questions about the study design (associations rather than causation), more importantly, the fact that statins could well identify the patient already at risk of developing diabetes and concluded that the benefit from statin therapy in reducing CV events far outweighs the minor risk of incident diabetes and LDL-C reduction with statins lowered cardiovascular risk even in low-risk patients. However, caution should be exercised in the low-risk primary prevention groups without significant elevations in LDL-C, especially the elderly.

\section{Conclusion and Future Perspectives}

Statin therapy is advocated as a primary prevention of CVD for moderate to high-risk diabetic patients with dyslipidemia and as a secondary prevention for those with/without risk factors and the incidence of new-onset diabetes should not result in dose reduction or withdrawal in these patients. There appears to be only a slight increase in new-onset DM whereas the cardioprotective effects of statins clearly outweigh its risks. It would be reasonable to implement lifestyle changes like weight reduction, aerobic exercises, and dietary modification to prevent diabetes rather than to stop statins in moderate to high-risk patients like the elderly and in those with insulin resistance, metabolic syndrome and established CVD who are on therapy for the appropriate reasons.

\section{Acknowledgement:}

I would like to thank my colleagues at the Chittagong Diabetic General Hospital, Institute of Applied Health Sciences and Cox's Bazar Medical College for their assistance in the writing and critically revising the manuscript.

Authors Contributions: S.R.C. and S.R.A were involved in data collection and drafted the manuscript. R.H.C. conceived the study. S.R.C and S.R.A. wrote the manuscript with input from all authors. S.R.A., R.H.C. and S.B. critically revised the final manuscript. All authors approved of the final manuscript for publication.

\section{References}

1. Lewington S, Whitlock G, Sherliker P, Richard Peto, Rory Collins, et al. (2007) Blood cholesterol and vascular mortality by age, sex, and blood pressure: a meta-analysis of individual data from 61 prospective studies with 55,000 vascular deaths. Lancet 370(9602): 1829-1839.

2. National Institute for Health and Clinical Excellence (2008) Lipid modification: Cardiovascular risk assessment and the modification of blood lipids for the primary and secondary prevention of cardiovascular disease.
3. Taylor F, Huffman MD, Macedo AF, Theresa HM Moore, Margaret Burke, et al. (2013) Statins for the primary prevention of cardiovascular disease. Cochrane Database Syst Rev 2013(1): CD004816.

4. Naci H, Brugts J, Ades T (2013) Comparative tolerability and harms of individual statins: a study-level network meta-analysis of 246955 participants from 135 randomized, controlled trials. Circ Cardiovasc Qual Outcomes 6(4): 390-399.

5. Abd TT, Jacobson TA (2011) Statin-induced myopathy: a review and update. Expert opin Drug saf 10(3): 373-387.

6. DiPiroJT, TalbertRL, Yee G (2011) Pharmacotherapy: A Pathophysiologic Approach. 8e.

7. Schachter M (2005) Chemical, pharmacokinetic and pharmacodynamic properties of statins: an update. Fundam Clin Pharmacol 19(1): 117125.

8. http://img.medscape.com/fullsize/migrated/577/060/tarc577060. fig1.gif

9. (2017) Third Report of the National Cholesterol Education Program (NCEP) Expert Panel on Detection, Evaluation, and Treatment of High Blood Cholesterol in Adults (Adult Treatment Panel III) final report. Circulation 106(25): 3143-3421.

10. Gaede P Vedel P, Larsen N, Gunnar V H Jensen, Hans-Henrik Parving (2003) Multifactorial intervention and cardiovascular disease in patients with type 2 diabetes. N Engl J Med 348(5): 383-393.

11. Costa J, Borges M, David C, Carneiro AV (2006) Efficacy of lipid lowering drug treatment for diabetic and non-diabetic patients: meta-analysis of randomized controlled trials. BMJ 332(7550): 1115-1124.

12. Heart Protection Study Collaborative Group (2002) MRC/BHF Heart Protection Study of cholesterol lowering with simvastatin in 20,536 high-risk individuals: a randomized placebo-controlled trial. Lancet 360(9326): 7-22.

13. Colhoun HM, Betteridge DJ, Durrington PN, Graham A Hitman, H Andrew W Neil (2004) Primary prevention of cardiovascular disease with atorvastatin in type 2 diabetes in the Collaborative Atorvastatin Diabetes Study (CARDS): multicenter randomized placebo-controlled trial. Lancet 364(9435): 685-696.

14. Kearney PM, Blackwell L, Collins R, A Keech, C Baigent, et al. (2008) Efficacy of cholesterol-lowering therapy in 18,686 people with diabetes in 14 randomized trials of statins: a meta-analysis. Lancet 371(9607): 117-125.

15. Knopp RH, d Emden M, Smilde JG, Stuart J Pocock, et al. (2006) Efficacy and safety of atorvastatin in the prevention of cardiovascular end points in subjects with type 2 diabetes: The Atorvastatin Study for Prevention of Coronary Heart Disease Endpoints in non-insulin-dependent diabetes mellitus (ASPEN). Diabetes Care 29(7): 1478-1485.

16. Cannon CP, Eugene Braunwald, Carolyn H McCabe, Daniel J Rader, Jean L Rouleau, et al (2004) Intensive versus moderate lipid lowering with statins after acute coronary syndromes. N Engl J Med 350(15): 14951504.

17. Ridker PM, Christopher P Cannon, David Morrow, Nader Rifai, Lynda M Rose, et al. (2005) C-reactive protein levels and outcomes after statin therapy. N Engl J Med 352(1): 20-28.

18. Shepherd J, Philip Barter, Rafael Carmena, Prakash Deedwania, et al (2006) Effect of lowering LDL cholesterol substantially below currently recommended levels in patients with coronary heart disease and diabetes: The Treating to New Targets (TNT) study. Diabetes Care 29(6): 1220-1226.

19. de Lemos JA, Michael A Blazing, Stephen D Wiviott, Eldrin F Lewis Keith AA Fox, et al. (2004) Early intensive vs a delayed conservative simvastatin strategy in patients with acute coronary syndromes: phase Z of the A-to-Z trial. JAMA 292(11): 1307-1316. 
20. Gaede P, Lund-Andersen H, Parving HH, Pedersen O (2008) Effect of a multifactorial intervention on mortality in type 2 diabetes. $\mathrm{N}$ Engl J Med 358(6): 580-591.

21. Coleman CI, Reinhart K, Kluger J, C Michael White (2008) The effect of statins on the development of new-onset type 2 diabetes: a metaanalysis of randomized controlled trials. Curr Med Res Opin 24(5): 1359-1362.

22. Rajpathak SN, Kumbhani DJ, Crandall J, Nir Barzilai, Michael Alderman, et al. (2009) Statin therapy and risk of developing type 2 diabetes: a meta-analysis. Diabetes Care 32(10): 1924-1929.

23. Preiss D, Seshasai SR, Welsh P, Sabina A Murphy, Jennifer E Ho, et al (2011) Risk of incident diabetes with intensive-dose compared with moderate-dose statin therapy: a meta-analysis. JAMA 305(24): 25562564.

24. Freeman DJ, Norrie J, Sattar N, Cobbe SM, I Ford, et al. (2001) Pravastatin and the development of diabetes mellitus: evidence for a protective treatment effect in the West of Scotland Coronary Prevention Study. Circulation 103(3): 357-362.

25. Ridker PM, Danielson E, Fonseca FA, Jacques Genest, John JP Kastelein, et al. (2008) Rosuvastatin to prevent vascular events in men and women with elevated C-reactive protein. N Engl J Med 359(21): 21952207.

26. Shepherd J, Blauw GJ, Murphy MB, Edward L E M Bollen, Brendan M Buckley, et al. (2002) Pravastatin in elderly individuals at risk of vascular disease (PROSPER): a randomized controlled trial. Lancet 360(9346):1623-1630.

27. Waters DD, Ho JE, DeMicco DA, Andrei Breazna, Benoit J Arsenault, et al. (2011) Predictors of new-onset diabetes in patients treated with atorvastatin: results from 3 large randomized clinical trials. J Am Coll Cardiol 57(14): 1535-1545.

28. Sattar N, Preiss D, Murray HM, Paul Welsh, Brendan M Buckley, et al. (2010) Statins and risk of incident diabetes: a collaborative metaanalysis of randomized statin trials. Lancet 375(9716): 735-742.

29. Simsek S, Schalkwijk CG, Wolffenbuttel BH (2012) Effects of rosuvastatin and atorvastatin on glycaemic control in type 2 diabetesthe CORALL study. Diabet Med 29(5): 628-631.

30. Rocco MB (2012) Statins and diabetes risk: Fact, fiction, and clinical implications. Cleve Clin J Med 79(12): 883-893.

\section{Your next submission with Juniper Publishers} will reach you the below assets

- Quality Editorial service

- Swift Peer Review

- Reprints availability

- E-prints Service

- Manuscript Podcast for convenient understanding

- Global attainment for your research

- Manuscript accessibility in different formats

(Pdf, E-pub, Full Text, Audio)

- Unceasing customer service

Track the below URL for one-step submission https://juniperpublishers.com/online-submission.php 